\title{
Hegemonik Erkeklik Krizi ve Yeni Türk Sineması'nda Erkeklik Halleri
}

\author{
Doğan Aydoğan (Dr. Öğr. Üyesi) \\ Karabük Üniversitesi İşletme Fakültesi \\ doganaydogan@karabuk.edu.tr \\ ORCID: 0000-0002-6808-9107
}

Başvuru Tarihi: 22.03.2019

Yayına Kabul Tarihi: 30.09 .2019

Yayınlanma Tarihi: 24.01.2020

DOI: http://10.17680/erciyesiletisim.543218

\section{Öz}

1990 sonrası sinema anlatılarına odaklanan çalışmalar, bu anlatılarda "erkeklik krizinin" önemli bir sorun olarak belirdiğini tespit etmektedir. Sosyolojik dönüşüme bağlı olarak hegemonik erkekliğin ve krizinin tartışıldığı koşullarda, sinema anlatıları da erkeklik sorununu merkezine taşımıștır. Bu çalışma 1990 sonrası anlatılarda ortaya çıkan çatışmayı modernleşme süreci anlatıları ile bir süreklilik içinde ele almaktadır. Geleneksel anlatılarda var olan çatışma ataerkil ideoloji'nin kadın konumunu gelenek, din, vatan ve aile gibi kavramlarla ele alması ile şekillendirilirken, 1990 sonrası anlatılarda kadın konumu bu tür toplumsal kavramlarla ilişki içinde ele alınamaz hale gelmiştir. Kadın konumunun bir üst anlatıya başvurarak ele alınamadığı bu anlatılarda erkeklerin konumu ve erkeklik belirgin bir sorunsal olarak karşımıza çıkmaktadır.

Üretilen metinler bu bağlamda bazı tematik bütünlükler üretmektedir. Erkek karakterin bir anti kahraman ve negatif özne olarak sunumu, öykünün geleneksel söylemlerle kapatılamayışına karşılık karakterin ölümü ya da açık uçluluk bu metinlerde belirgin bir eğilimdir. Şimdiki zaman ve buradaki mekânda yaşanan istikrarsızlığa karşı zaman ve mekânı yadsıyarak erkek kimliğini tehdit etmeyen anlatıların üretilmesi önemli bir eğilim olarak belirmektedir. Buna karşı şimdiki zaman ve mekânı konu edinen metinlerde anlatıların kadınsızlaşması, kadın düşmanlığı ya da kadının salt arzu nesnesi olarak ele alınması belirginleşmektedir. Ek olarak erkek dayanışması ve babanın aranışı, susan ya da konuşamayan erkek karakterlerin çoğalması ve bu erkeklerin ürettiği çok yönlü şiddet bu filmlerde tekrar eden önemli bir motiftir. Öykülerin merkezini erkekliğe yönelik bunalım söylemleri alsa da öykülerin erkek merkezli olmaya devam ettiği görülmektedir. Ek olarak cinsiyet ve erkeklik kavramlarının, anlatılarda farklı alanlara yayılan konuları belirleyen bir üst-ilke şeklinde konumlandığı görülmektedir.

Anahtar Kelimeler: Hegemonik Erkeklik, Yeni Türk Sineması, Toplumsal Cinsiyet, Sosyoloji. 
Research Article

\title{
Crisis of Hegemonic Manhood and Masculinity Forms in New Turkish Cinema
}

\author{
Doğan Aydoğan (Asst. Prof. Dr.) \\ Karabük University Faculty of Management \\ doganaydogan@karabuk.edu.tr \\ ORCID: 0000-0002-6808-9107
}

Date Received: 22.03.2019

Date Accepted: 30.09 .2019

Date Published: 24.01.2020

DOI: http://10.17680/erciyesiletisim.543218

\begin{abstract}
Studies focusing on the narratives of cinema after 1990 have found that the crisis of masculinity appears to be an important problem in this narratives. In the conditions which hegemonic masculinity and crisis discussed due to sociological transformation; cinema narrations have also brought the masculinity problem to the center. This study debates the conflict that emerged in the narratives after 1990 with a continuity of narratives of modernization process. While the conflict existing in traditional narratives is shaped by patriarchal ideology considering the position of woman in terms of tradition, religion, homeland and family, in the narratives after 1990 the position of women in narratives became inextricable in relation to such social concepts. In these narratives, where the position of women cannot be addressed by referring to a meta-narrative, the position of men and masculinity appear as a significant problematic.
\end{abstract}

Produced texts contains some thematic reiterations in this context. The presentation of male character as an anti-hero and negative subject, the death of the character or openended narration is a significant tendency in these texts because of the story cannot be closed with traditional methods. The production of narratives that do not threaten male identity by denying time and space against the instability experienced in the present time and space appears as an important tendency. On the other hand it becomes evident in the narrations consist in present time and space; stories without women, enmity against women or woman such as an object of desire. In addition, male solidarity and the search for the father, the silence of male characters who are not or unable to speak and the multifaceted violence produced by these men are an important theme that repeats in these films. Although the narratives argues masculinity discourse in central to the stories it is seen that the stories continues to be male centered. In addition, it is seen that the concepts of gender and masculinity are positioned as a meta-principle that determines the subjects of narratives spreading to different fields.

Keywords: Hegemonic Masculinity, New Turkish Cinema, Gender, Sociology. 


\section{Giriş}

1990’lı yıllarla birlikte Türk Sineması'nın farklı bir üslup geliștirdiği ve ortaya çıkan anlatılar içinde erkeklik kavramının önemli bir yer işgal ettiği görülmektedir. 1980 sonrası sinema anlatıları -askeri darbenin de etkisi ile- önce kadının toplumsal konumu ve ardından erkeklik bunalımını perdeye taşımış̦tır. Bununla birlikte erkeklik krizinin metinlere Türkiye modernleşmesinin fiili başlangıcı olan Tanzimat Dönemi ile yerleştiğini söylemek mümkündür. Bu bağlamda toplumsal cinsiyet kalıplarındaki dönüşüm ve çatışmanın, özgün modernleşme tarihiyle paralellik gösterdiği görülmektedir.

Tanzimat Dönemi'nin metinlerde cinsiyet üzerinden yeni bir söylem üretmesinin arkasında ataerkil sistemin hiyerarșik toplum yapılanması ile Avrupa Modernliği'nin eşitlik kavramı üzerinden kurduğu toplum yapısı arasındaki temel çelişki yatmaktadır. $\mathrm{Bu}$ gelişme erkeklerin simgesel düzen ile özdeșleșerek edindikleri himayeci kimlik ile anayasal devletin eşitlik üzerinden geliştirdiği eşitlikçi kimlik arasında, erkeklik açısından nitelikli bir kırılma ve hegemonyanın üretim gerekliliğini doğurmuștur.

Tanzimat ile birlikte, cinsiyetlere dair iki farklı söylemin çatışması ve uzlaşı girişimi metinleri belirlemeye başlamıștır. Bir tarafta ataerkil kültürün himayeci dünya görüşü diğer tarafta bürokratik-kapitalist modernliğin cinsiyetleri para ve yasa aracıllğılyla teorik bir eşitlik üzerinden ilişkiye sokuşu ve bu iki dinamik arasındaki uyuşmazlık metinlerde varlığını sürekli hissettirmiş ancak metinler nihai aşamada geleneksel ideolojinin kültürcü hegemonyasına göre şekillenmiştir. Modernleşme süreci boyunca varlığını koruyan bu birliktelik ve geleneksel görüşün metinler üzerindeki hakimiyeti, 1980 sonrası gelişen toplumsal yapıda işlerliğini kaybetmiş ve metinler geleneksel anlatı kalıpları ile ele alınamaz hale gelmiștir. 1980'lerde öyküde merkezi konumunu kaybeden erkek özneler, 1990 sonrasında ortaya çıkan anlatılarda öykünün merkez konumuna negatif ve başarısız özneler olarak gelmiş buna karşı kadın karakterler öykünün ve perdenin dışına itilmiştir. Eş zamanlı olarak Tanzimat ve Cumhuriyet Dönemi edebiyatının toplumsal cinsiyet ve aileye yönelik öyküleri sinema ve televizyon anlatılarında tekrar ele alınmış ve toplumdan önemli bir karşılık bulmuștur. Bu durum geleneğe dayalı cinsiyet kalıplarında nitelikli bir kırılmayı ve süreklilik arayışını işaret etmektedir. Kültür Endüstrisi bir taraftan erkeklik bunalımına odaklanan metinler üretirken diğer taraftan kentin ve şimdiki zamanın bunalımlarına karşı erkek kimliğinin tehdit edilmediği geçmişe ve kent dışına yönelen kaçış ve nostaljiye dayalı metinler üretmiştir.

Kadının konumu, aile, erkeklik ve şiddet günümüz Türkiye'sinin önemli toplumsal sorunlarından biridir. Boşanma ve cinsiyetten kaynaklanan şiddet istatistikleri erkekliğe yönelik hegemonik söylemin işlevsizleștiğine veya bir krize girdiğine dair önemli göstergeler olarak okunabilir. Görsel iletişim araçlarında toplumsal cinsiyet kalıplarının temsili ile toplumsal yaşam arasında karşılıklı bir ilişki vardır. Bu nedenle görsel medyada yer alan metinlerin erkekliği ele alış biçimlerinin incelenmesi tarihsel derinliği olan bir sorunun güncel analizi açısından önemlidir. Bu bağlamda çalışma bakış açısını tarihsel eleștiri üzerinden șekillendirmekte ve tarihsel koşulların, cinsiyet ve toplum ile ilişkisini vurgulayarak sosyolojik analize yaslanmaktadır (Özden, 2004, s. 154). Metinlerde ortaya çıkan tematik bütünlük, tekrar ve stratejilerin; erkeklik ve toplumsal cinsiyet üzerine yapılacak çalışmalara kaynaklık edebileceği düşünülmektedir.

\section{Erkeklik, Himayecilik ve Eşitlik}

Erkeklik ve kadınlık toplum tarafından üretilen bazı kalıpları tekrar ederek üretilen iktidar ile ilintili ve tarihsel bir olgudur. Bu nedenle kültürden kültüre ve zaman içinde 
değişir (Atay, 2004). Bu bağlamda erkeklik evrensel bir norm değil, toplumsal etkileşime dayalı sürekli üretilen bir performanstır. Erkekliğin ve kadınlığın üretiminde erkeklik ve kadınlık içsel bir ilişki içindedir. İki kavram birbirleri ile ilişki içinde anlam kazanırlar (Maral, 2004).

Cinsiyetlerin konumlanmasında ataerkil ideolojinin belirleyici bir rolü söz konusudur. Ataerkil ideoloji, kökleri dinsel metinlerden daha öteye uzanan bir toplumsal yapı üretir. Erkeklik, teknolojik ve kültürel gelişim içinde kurulan hiyerarşik düzenin kültürel, dilsel, ideolojik ve siyasal olgularla ilişki içinde üretildiği bir biçimlenmedir. Pazarlığa açıktır ve dönüşebilir, ancak nihai aşamada kendini sürekli yeniden üretmeye çalışan sistem üstü bir olgudur. Erkeklik tanımları kültürlere göre değișim gösterse de "dölleyici, koruyucu ve geçindirici" olma niteliği genel bir tanım sağlar. Bunun arkasında yatan neden kimliklenme sürecinde yaşanan farklılıktır. Kız çocuk büyüme aşamasında annesi ile devamlılık ve yakın ilişki içinde bir kimliklenmeye sahipken, erkek çocuk babası ile aynı yakın ilişkiyi kuramaz. Babanın uzak modelliğinden ve anne ile olan ilişkinin kesilmesinden sonra erkek çocuk, cemaatin idealleri tarafından tanımlanmış erkeklik söylemi ile yüzleşir ve çocuk olmasından kaynaklanan bir güçsüzlük hissine kapılır (Demren, 2019). Bu nedenle erkeklik sürekli kazanılması gereken bir performans, cemaatin savaşçı ve korumacı taleplerine uyum sağlayan bir güçlülük/güçsüzlük halidir. Cemaat tarafından talep edilen erkeklik şerefinin elde edilmesi, korunması ya da elden çıkma olasılığı saldırgan ve şiddete dayalı bir cinsiyet kimliğine ișaret eder.

Ataerkil ideoloji ürettiği simgesel hegemonik erkeklik sayesinde toplumsal bir hiyerarşi üretir. Cemaatin korunması, soyun devamlılığı ile kan bağını temel alan bu yapılanmada erkek kişi cemaatin korunmasından ve devamlılığından sorumlu himayeci bir kimlik ile yapılandırılır, bu bağlamda erkeklik bireysel bir tercih olarak şekillendirilmez. Erkeklik, erkek olmayan (kadın, çocuk, yaşlı) diğer cemaat üyelerini himaye etmekle yükümlü bir özne olarak üretilirken toplumsal bir eşitsizlik üretir. Ancak hegemonik erkeklik, erkekler arasında da bir hiyerarşi üreterek ideal erkekliği sürekliği yeniden üretmeye girișir. Bu bağlamda erkeklik kavramı ile eşitlik kavramı arasında teorik bir çatışma vardır.

Toplum, biyolojik yaşamı aşan yapıların üretimi ve bu yapıların sürekli dönüşümü ile var olmaktadır. Simmel'in (2005, s. 57) ifadeleri ile "hayat" kendi kendine yeten formlar üretme ve bu formların sınırlarının zorlanarak aşılmasından oluşan dinamik bir süreç, bir etkileşim halidir. Hayatın kendini ifade ettiği dönemsel formlar kültürü oluşturur. Kültür, gelenek halini alarak mitleşir. Ancak toplumsal yapılar tarafından üretilen bir form olarak kültür, yapılardaki dönüşüme bağlı olarak dönüşüme uğrar. Avrupa modernliği bu bağlamda nitelikli bir kırılma ve çatışma barındırır. İnsan hakları ve yurttaş kavramının ürettiği teorik eşitlik fikri ile tarım toplumundan devralınan ataerkil kültür arasında eşitlik ve himayecilik ${ }^{1}$ bağlamında nitelikli bir karşıtlık var olmuş ve her zaman kendini hissettirmiştir.

Bürokratik kapitalizm altyapı ve üstyapıya bağlı olarak ortaya çıkardığı iki olgu ile tarım toplumuna dayalı geleneksel kadın-erkek konumlarını yerinden etme potansiyeli taşımaktadır. İlk olarak yasal otoriteye dayalı bürokratik toplum nihai aşamada anayasal eşitlik fikrine dayanmak durumundadır. Anayasal eşitlik ilkesi, kadın ve erkek arasında hukuksal eşitliği barındırmakta ve bu durum Türkiye özelinde şer-i ve örf-i hukuk ile gündelik yaşamda uygulanan geleneksel pratiklerin erkek lehine düzenlemelerini istikrarsız hale getirmektedir. Anayasal eşitlik fikrine ek olarak endüstriyel kapitalizm, emek ve sermaye kavramlarında yeni bir bağlam oluşturmuştur. 18. yüzyılda 
zorunlu ve kurallı çalışma yerini çalışma özgürlüğünün zorunluluğuna bırakmıştır (Castel, 2017, s. 165).

Bürokratik-kapitalizm kadın ve erkeğin toplumsal cinsiyet kalıplarına yönelik devrimci potansiyeller taşısa da işin örgütlenmesi, tasarlanması ve yapılması makine kapitalizmi boyunca erkek lehine bir süreç doğurmuş ve erkek egemen ideoloji kadın kimliğini uzun süre baskı altında tutmayı başarmıştır. Özellikle ücretli emeğin tanımı ve cinsiyetlere göre ayrışması toplumsal cinsiyet rollerini etkilemiştir (Connell, 1998, s.184). Teorik olarak eşit yurttaşlık ilkesine yaslanan anayasal modern devlet, özel alanı kültürel ön kabullere bırakarak cinsiyetler arası eșitsizliğe bir süreklilik kazandırmıştır (Berktay, 2010, s. 37-47). Süreç boyunca gelenek, din ve milliyetçilik gibi kavramlarla eşitlenen cinsiyet konusunda belirgin bir kırılmanın yaşanması İkinci Dünya Savaşı sonrası yaşanan gelişmelere bağlıdır.

İkinci Dünya Savaşı'ndan sonra ortaya çıkan bilgi temelli üretim, sermayenin küreselleşmesi ve kentleşme gibi gelişmeler, üretim biçimi, eğitim, göç, rekabet gibi birçok alanda nitelik bir dönüşüm yaratarak toplumsal cinsiyet ilişkilerini de dönüştürmüştür. İkinci Dünya Savaşı'ndan sonra ortaya çıkan bir diğer önemli gelişme, kentleşmeye dayalı refah toplumu yaratma projesidir (Keyder, 2004, s. 9-10). Kentleşme, geleneğe dayalı insan ilişkilerini yasa ve sözleşmeye dayalı yeni bir bağlama yerleştirme niteliği taşır. Marx'ın "katı olan her şey buharlaşıyor" şeklinde ifade ettiği bu durum geleneksel statüye bağlı toplumsal kalıpların istikrarsızlaşmasını içerir. Modernliğin statüye bağlı ilişkilerden kopardığı insan ilişkileri pratik zeminini ancak kentleşme ve kentleşmeye dayalı toplumsal ilişkiler bağlamında üretebilmiştir.

\section{Tanzimat’tan Bugüne Himayecilik ve Eşitlik Karşıtlığı}

Osmanlı Devleti toplum yapısı var olanın sürdürülmesine dayalı ve toplumsal düzenin baba/padişah tarafından güvence altına alındığı bir tarım toplumu niteliğindedir. Simgesel düzenin padişahın simgesel gücü tarafından düzenlendiği ve toplumsal yapının sıkı bir istikrar politikası ile korunduğu bu yapıda toplumsal roller ve ilişkiler uzun süre istikrarlı varlığını korumuştur. Ancak Avrupa Modernliği'nden kaynaklanan düşünsel ve iktisadi gelişmeler Osmanlı toplum yapısını sarsmış ve Tanzimat Fermanı nitelikli bir dönüşümün iktisadi-hukuksal zeminini oluşturmuştur. Bu dönüşüme bağlı gelişmeler kültürel alanda başlayan bir dönüşümü ve çatışmayı da beraberinde getirmiştir. Bu gelişmeleri devletin kültürel hegemonya merkezi olan İstanbul'da yaşanan gelişmeler ve oluşan karşıtlıklar ile birlikte ele almak mümkündür.

İstanbul, Tanzimat döneminde önemli yapısal dönüşümlere ve buna bağlı gelişmelere sahne olmuştur. İstanbul'da yaşanan kentleşme ve nüfus artışı Anadolu ve Rumeli'den nitelikli işçilerin aileleriyle birlikte İstanbul'a göç ettirilmesini gerekli kılmıştır. Kentin yeniden yapılanmasında işlevsel bir rol üstlenen bu aileler aynı zamanda orta tabakanın oluşumunu da barındırmaktadır. Kentin yeniden inşa edilen bölümlerinde ortaya çıkan sıra evler ve apartmanlar bu sınıfın varlığının göstergesi niteliğindedir (Tekeli, 2006). $\mathrm{Bu}$ dönemde büyüyen bir diğer toplumsal tabaka da bürokratik devlet işleyişine dayalı gelişen üst düzey memurların oluşturduğu tabakadır. İktisadi yaşama bağlı ortaya çıkan bu gelişmeler; aynı zamanda Pierre Bourdieu'nun (2015, s. 90) iş bölümü ve cinsiyetlere dayalı olarak tanımladığı ayrımların da belirginleșmeye başladığı bir yapılanmayı oluşturmuştur. Giyim kuşam, ev düzeni, kişiler arası münasebetler bu ayrımlar tarafından şekillendirilmeye başlamıştır². 
Bu dönemde ortaya çıkan önemli bir farklılaşma da aile kurumu üzerinde gerçekleşmiştir. Kalifiye orta tabakaların aile değerleri zanaatkar kesimin geleneksel değerlerini barındırmakla beraber, bu değerleri hayatın değișim sürecine uyarlayabilecek dinamiklere de sahiptir. Buna karşın ilmiye sınıfı ulema ve yeni gelişen bürokrasiye dayalı iki farklı aile modeli ve adab-ı muaşeret anlayışı doğurmuştur. Ulema sınıfı, içe kapalı ve akraba evliliğine dayalı geleneksel yapılanmasını sürdürürken, bürokrasiden kaynaklanan tabaka, herhangi bir toplumsal kökene sahip olmadıkları için farklı kültür çevrelerinin mirasını devralmış ve bu tabakanın ürettiği davranış kalıpları modernleşmenin de göstergesi olmuştur (Işın, 2006).

Bu tabakaların ürettiği kültürel ayrımlar; çatışma ve çözüm arayışlarının da taşıyıcısı olmuştur. Bürokrasi tabakasının ürettiği aile yaşantısı tüketim temellidir ve özellikle gençlerin ve kadınların yaşamında bir özgürleşmeyi barındırmaktadır (Işın, 2006). $\mathrm{Bu}$ dönemin kanaat önderleri aile ve kadın konularını himayecilik ve toplumsal yapı kavramları ile ele almış ve geleneksel ailenin modern adab-ı muaşeret ile nasıl uyumlu hale getirilebileceğini kendi bakış açıları üzerinden açıklamaya çalışmıştır. Toplumsal tabakalaşmanın belirginleștiği, hareketlendiği ve iktisadi hayatın gündelik yașamı belirlediği bu dönemde aileye bağlı olarak kadın davranışlarında da ayrımlar oluşmuş ve bu farklılıklar himayeci anlayış tarafından eleştirilmiştir ${ }^{3}$. Bu dönemde kadını gündelik hayata sokan iki önemli gelişme yaşanmıștır. Birincisi modern eğitimin kabul edilmesi ve gündelik hayata yönelik kadın meslek okullarının (ebelik, kız sanayi mektebi ve Darülmuallimat) açılmasıdır. Bir diğer gelişme ise konak içi eğitim faaliyetlerinin yaygınlaşmasıdır ${ }^{4}$ (Işın, 2006). Kadın davranışı, toplumsal konumu ve gündelik yaşamdaki yeri ile ailenin yaşadığı dönüşüm Tanzimat Devri kültür ürünlerine de yansımış ve baba otoritesinin yokluğunda, "arzunun" ve "kadının" peşine düşen oğulun yok ettiği, dağıttığı aile motifi romanlara yerleşmiştir (Parla, 2009, s. 19). Bütün bu gelişmelere rağmen, kamusal alanda kadın ve erkeğin bir arada bulunmayışı edebiyat eserlerine de yansımıștır. Bu dönem edebiyatında yetkin kadın karakterler ve diyaloglar yoktur. Kadın, erkek ilişkilerinin tasvirinde bir yetersizlik söz konusudur (Ortaylı, 2014, s. 160-161). Bu nedenle kadının toplumsal konumu üzerine yazılan yazılar ve eleștiriler, kadın ve kamusal alan meselesini erkek merkezli; toplum, aile ve gelenek ile ilişki içinde ele almıştır.

Tanzimat ile ortaya çıkan yapıda bir sentez değil "mülemma" söz konusudur. Mülemma, eski ile yeninin birleşmesini ifade etmez; yeni bir kültürü benimsemek değil beğenmek, eski olanı terk etmemek fakat bir terkibe de ulaşamamaktır (Parla, 2009, s.12-13). Eskinin gözetiminde yeni olanı yaşamanın mülemması Türkiye modernleşmesinin ve anlatılarının temel motifi olmuştur. Ataerkil kültürün denetimi olmaksızın, para ekonomisi ve yasal eşitliğin erkek kimliği üzerine yarattığı baskı ile hazzın ve arzunun babanın yokluğunda nasıl konumlandırılacağına karşı bir ilmihâl'den yoksun aydınlar için bu dönemde başlayan erken bir tema "babanın aranıșı" olmuştur . Baba'nın aranışı, erkekliğe simgesel üstünlügünü veren hiyerarşik geleneğin davet edilmesinden kaynaklanmaktadır. Hukuksal eşitlik fikri, himayeci erkekliğin biricik konumunu yerinden etmekte bu da kardeşler hukukuna dayalı Avrupa modernliğine karşı içsel bir direnci üretmekteydi. Bu nedenle modernliğin somut ürünleri kolayca kabul edilip, içselleştirilirken, düşünsel boyutlarına yönelik önemli bir direnç yükselmekteydi. Eşitlik fikri teorik olarak hukuksal metinlerde yer alırken, özel hukuk ve kültürel hayat ataerkil himayeciliğin talepleri ve direnişleri ile şekillenmiştir. 
Tanzimat ile başlayan farklılaşma ve çatışma kadın hareketlerinin yükselmesi ve kadınların toplumsal taleplerini dile getiriși ile devam etmiștir. Kadınların hukuksal ve siyasi hakları Cumhuriyet ile birlikte sağlanmış olsa da ${ }^{6}$ kadın konumunun geniș ve genel bir anlamda dönüşümü 1950'lerde başlayıp etkileri günümüzde devam eden kentleşme olgusu ile gerçekleşmiştir. Osmanlı modernleşme süreci kadın haklarını iyi bir anne ve iyi bir eş olma düsturu ile ele alırken (Avcl, 2009), Milliyetçi gelişme kadını vatan-eğitimnamus gibi kavramlarla birlikte toplumsal bir varlık olarak ele almıștır. Türkiye Solu'da kadınlık meselesini sosyalizm ve devrim gibi konular karşısında geriye itmiştir (Berktay, 2010, s. 88-111). Küreselleşme, kentleşme ve 1950’lerde kente göç eden kitlelerin kız çocuklarının eğitim ve iş yaşamına daha fazla dahil oluşu; kadınlık meselesinin kültürel kalıplar altında eriten söylemlerin işlevsizleşmesine yol açan pratik gelişmelerdir. 1960 sonrası yükselen 2. Feminist dalganın yarattığı düşünsel arka plan ise kadının ve toplumsal cinsiyetin, toplumsal sembollerle eşitlenemeyecek tekil bir mücadele alanı olduğunu gösteren teorik gelişme olmuştur. Bu bağlamda himayecilik ve eşitlik şeklinde ele alınabilecek çatışma bağlamının, modernleșme süreci boyunca tarihsel bir süreklilik arz ettiği görülmektedir.

\section{Cinsiyetlerin Medyada Temsili ve Erkeklik}

Toplumsal cinsiyet kapalı iki yapı arasındaki bir tahakküm ilişkisi değil, toplumsalı oluşturan birçok unsurun etkileşiminden doğan sürekli bir oluş ve üretilen hegemonya halidir. İdeoloji bu etkileşimi mitleştirilmiş bazı kalıplarla düzenleme yoluna gider. Ancak toplumda kadının ve erkeğin rolü değiștikçe, medyada üretilen ve kullanılan cinsiyet mitleri de değişmektedir (Fiske, 2013, s. 187-188). Cinsiyetlerin medyada veya kültür endüstrisinin diğer alanlarında temsili değișse de erkekliğe dayalı iki farklı eğilim modernleşme süreci boyunca anlatıları şekillendirmiştir; kadının kontrol altına alındığı ve erkekliğin tekrar üretildiği veya üretilmediği metinler ile kadının bir arzu nesnesi olarak kullanılarak erkekliğin performansa davet edildiği metinler. Bu bağlamda kültür endüstrisi ürünlerinin yakın zamana kadar, bugün de büyük oranda devam eden biçimde erkek merkezli bir yapı sergilediği görülmektedir. Hem Avrupa'da hem modern Türkiye metinlerinde görülen bu eğilimde biyolojik kadınlık ile toplumsal kadınlık ayrılmış ve erkekliğin taleplerine ve geleneğe uyan kadın ile bu taleplerin dışında kalan istenmeyen bir karşı kadın karakteri var olmuş ve bu iki kadın tipi öykülerde önemli bir işlev üstlenmiştir (Moran, 2017, s. 252-254). Bu durum eşitlik, himayecilik ve arzu arasında bölünen erkek kimliğinin metinlere yansımış ifadesidir.

Ancak çalışmanın sınırlılığı açısından burada edebi metinlere yönelik bir inceleme yapılmaksızın görsel metinlere ve cinsiyete yönelik politikalarına odaklanılacaktır.

Anlatıları belirleyen politikanın kadının bedeni ve toplumsal konumu üzerinden ifade edilmesi anlatıyı şekillendiren geleneksel bakışın erkek merkezli olmasından kaynaklanır. Mulvey’e (1989) göre sinemada gözetleme fantezisi hâkimdir ve gözetleme edimine erkek bakışı hakimdir. Öyküde ve anlatının perdeye yansıtılış biçiminde aktif bakan erkek ve pasif bakılan kadın ayrımı göze çarpmaktadır. Erkek karakterler aktif ve olayları denetler biçimde konumlanırken, kadın karakterler olayların öyle olması için bir gerekçe oluşturan bir arzu nesnesidir. Erkek, kadını ya sürekli gözetlemekte ve denetim altında tutmakta ya da yıldızlaştırarak, fetiş bir nesneye dönüştürmekte ve gerçekliğin ötesine itmektedir (Mulvey, 1989).

Buna karşın modern ekonomi ve bürokratik örgütlenmenin gereklilikleri, insanın özerkliğini sınırlayan ve insanı baskılanmış bir gündelik yaşamın üyelerinden biri haline 
getiren toplumsal bir yapılanmayı beraberinde getirmiștir (Lefebvre, 2007, s. 82-124). İnsanın bir demir kafes içindeki rutin hayatı iki farklı şekilde tatmin edilebilir; konformist yaşam tarzı ve arzunun sürekli yeniden üretilmesi. Her ikisi de kapitalist modern ideolojinin kışkırttığı ve kendini sürekli üretebilmek için kullandığı alanlar olmuştur.

Hegemonik erkekliği bütünlemeye/tekrar onaylamaya yönelik bir öykü ve anlatı oluşturması gereken geleneksel sinema metni, öyküleri ego bütünlügünün sağlandığı bir kapanımla sonlandırma çabası içindeyken; tüketim ihtiyacı yaratmak için arzuyu ve arzuya dayalı eksiltme/tamamlanmamışlık üretmeye çalışan reklam metni cinsiyet, beden ve arzu ilişkisine daha pragmatik yaklaşır ve erkekliği rekabete açar. Kısacası popüler görsel metinler erkekliğin onarılması veya erkekliğin ispatı için arzuya ve performansa davet edilmesi șeklinde gelişen iki ana eğilim içinde ancak hep erkek merkezli bir dil oluşturmuştur.

Popüler metinlerde erkek bakmak ve arzulamak zorunda olan bir erkek olarak konumlandırılırken, kadın kendini bu bakışa göre tasarlamak zorunda olan bir nesne/ özne olarak konumlanır (Lefebvre, 2007, s. 87) (Berger, 2014, s. 47). Geroge Herbert Mead ise (2017, s. 180-181), benlik oluşumunda "genelleștirilmiş öteki" kavramsallaștırması ile özneyi izleyen ve davranışı oluşturan genel dışsal bakışı ortaya koymuştur. Mead'e göre ben, öteki ve genelleştirilmiş öteki arasındaki etkileşim sembollerin dolaşımına bağlıdır. Egemen erkeklik, bu sembollerin düzenleniş ve yönlendirilmesi ile her iki cinsiyeti de belirlemektedir. Kadını bir arzu nesnesine dönüștüren bu bakış, erkeği "hegemonik erkeliğin" rekabetçi dünyasına davet etmekte ve erkekliği de üretmektedir (Connell, 1998, s. 123). Bu bağlamda erkek merkezli metinler yalnız kadının toplumsal konumunu değil, erkeğin ve erkekliğin toplumsal konumunu da inşa eder.

\section{Hegemonik Erkekliğin Krizi ve Farklılaşan Temsil Politikaları}

Erkeğin erkekliğini üretmesinde; kadın tarafından dışarıdan, koşulsuzca üretilen ve sürekli tekrarlanan takdir mekanizması önemli bir rol oynamaktadır. Bu koşulsuz takdir mekanizması geleneksel anlatılarda temel bir konum işgal etmiştir. Geleneksel anlatılarda ve reklam metinlerinde erkeğin eylemini onaylayan kadının bakışı ve varlığı/ yokluğu stratejik bir işlev sağlar. Sinema metni bu takdir mekanizmasını kahramanın öykü içinde ispatladığı erkek/özne konumunu onaylayarak yaparken, reklam metni tüketim ile ilişkilendirir. Bugün, erkekliğin ihtiyaç duyduğu ve her zaman hazır bulduğu takdir mekanizması gerek toplumsal cinsiyet kalıplarının ürettiği davranış biçimlerinin değişmesi, gerekse iktisadi koşulların kadın ve erkek kategorilerini bir arada küresel bir rekabet ve performansa sürüklemesi tarafından yok edilmektedir.

Kapitalizmin geldiği son aşama, kentleşme ve feminist hareketin ürettiği itiraz ile erkeklik, dışarıdan talep ettiği koşulsuz onayı alamamakta bu da erkeğin kendine yönelik bir bakış geliștirmesine yol açmaktadır. Bu noktada vücut geliștirme, kendi vücuduna odaklanma ve narsist bir beden fetişizmi işlevsel roller üstlenmektedir. Erkekliğin üretiminde bedenin sportif faaliyetlerde olduğu gibi işlevselleştirilmesi önemli bir kalıptır (Onur ve Koyuncu, 2004) (Connell, 1998, s. 123). Dışarıdan kendisine yönelen takdir mekanizmasını ve iktidarını kaybeden erkeklik, kendi kendine bakmak, bedenini projelendirmek gibi ego merkezli stratejiler geliştirmektedir. Geleneksel anlatılarda bedeni ile teatral bakışın merkezinde yer alan hep kadın olmuștur. Bugün tüm bedenler bu teatral sunuma göre tasarlanır hale gelmiştir (Kahraman, 2010, s.18). Küreselleşme ve küreselleşmeye dayalı toplumsallığın ürettiği mikro şiddet erkekleri de kadınlar kadar bedenleri ve kendileri üzerine düşünmeye zorlamaktadır (Han, 2015, s.89). 
Türk Sineması'nda 1980'lerde yükselen kadın filmlerini 90’lı yıllarda başlayan ve halen devam eden erkek filmlerinin takibi ile bu filmlerde yer alan yoğun bunalım, erkeklik krizini açıkça ortaya koymaktadır (Ulusay, 2004). Anlatılarda erkeklik kavramı ile ilişkili olarak evlilik, kadın, fahişe gibi konular Türk Sineması'nın ilk örneklerinde dahi karşımıza çıkmaktadır (Colin, 2006, s.2). Geleneksel anlatıları, Yeni Türk Sineması'ndan ayıran unsur kötü yola düşen ya da kötü olan kadınların bu davranışlarının arkasında bir sebep olmasıdır. Onlar kötü yola düşmüş ya da tecavüz gibi bir olay sonucu kötü yola düşürülmüştür (Colin, 2006, s.5). Bu filmlerde kadınlar himayeci ideolojiden tarafından affedilmeyi bir şekilde hak etmesi gereken tiplemeler olarak çizilmiştir. Affedilmeyi talep etmiyorsa bu kadınlar klişe bir "kötü" olarak ailenin ve geleneğin karşısında yer almışlardır. Arzu, cinsiyet ve çatışma hangi kavramlar etrafında kurulursa kurulsun metin nihai aşamada "aile" kurumunu koruyup, yücelten bir dil ile sonlanmıştır .

80'li yıllarda yükselen sinema ise ya aileyi yadsımış ya da ailenin çözülüşünü resmetmiştir (Colin, 2006, s.27). Bu dönemden sonra beliren anlatılar geleneksel içe kapanma, kötü kadını dıșta bırakma ve aileyi tekrar onarma stratejisi ile devam etmez. Bu dönemin kötü kadınları af dilemez, kötü yola düşüşlerini açıklayan romantik bir öyküye sahip değillerdir. Demiray (1999, s. 262) çalışmasında incelemiş olduğu filmlerde 1960 ve 1980 yılları arasında çekilen filmlerde ailenin sevgi işlevini koruduğunu, 1980 sonrası çekilen filmlerde ise ailenin sevgi işlevinin azaldığını tespit etmiştir. Geleneksel anlatıları şekillendiren aile ve kadın söyleminin 1980 sonrası Türk Sineması'nda güçsüzleștiği ve farklılaştı̆̆ı görülmektedir.

Yllmaz Güney'in yazdı̆̆ı ya da yönettiği Umut (1970), Sürü (1978) ve Yol (1981) gibi filmlerde kendini açığa vuran erkekliğin ele alınışındaki yenilikler, 1980’lerde kadın filmleri denilen eğilim ile yeni bir boyut kazanmıștır. Züğürt Ağa (1985) ya da Muhsin Bey (1987) gibi örnekler geleneksel statüye dayalı erkekliğin çözülüşünü ve erkeklik kavramının müzakereye açılışını konu edinirken, öykülerini himayeci erkekliği rahatsız etmeyecek bir söylemle sonlandırırlar. 1990 sonrası yapımlarda ise klasik anlatıları biçimlendiren himayeci söylem işe yaramamaktadır. Bu dönem sinemasının erkek kimliğine ve karakterlerine bu kadar odaklanmasının bir diğer sebebi ise erkekliğin ve ataerkil ideolojinin modern kent yaşamına dair üretilmiş bir dile sahip olmayışıdır. Hegemonya bir denge halidir. Her hegemonya bir itiraz, mücadele ve yeniden denge halini üreterek kendini var eder (Roper, 2005). Ancak hegemonik erkeklik bir müzakere ve denge üretmek yerine sürekli kendine odaklanan söylem üretmektedir. Müzakere ve yasanın oluşamaması şiddet ile sonuçlanır, bu durum hem anlatılarda hem de gündelik hayatta artan şiddet vakalarında kendisini açık bir biçimde göstermektedir.

Erkeklik krizi aslında üstü örtülü bir gelenek krizini barındırmaktadır ki geleneğin krizi tek boyutlu sonuçlar üretmemektedir. Geleneğin krizi ve modernitenin akışkanlığl ideolojilerin katı duvarlarında büyük aşınmalar yaratmaktadır, yaşanan süreç bilinen normlara uyulmayan bir kriz anı değil, karar vermenin imkansızlaștığı bir karar verilemezlik halidir (Bauman, 2000, s.152-154). Küreselleşmenin, doğal bir sonuç olarak küreselleşme karşıtı milliyetçilikleri üreterek çatışmalı bir bağlam yaratması gibi (Ritzer ve Stepnisky, 2014, s.580-612); geleneğin ve erkekliğin krizi de tek yönlü, determinist bir süreç değildir. Saldırı, şiddet, savunma, melankoli, hedonist arzu ve reddetme bu sürecin ortaya çıkardığı çok yönlü gelişmelerin bazılarıdır. 


\section{Yöntem}

Çalışma, üretilen metinleri tarihsel koşulların bir dışavurumu olarak ele alan tarihselci yaklaşıma göre ele almaktadır (Kabadayı, 2013, s. 63). Metinlerde süreklilik arz eden erkeklik ve aileye dayalı kalıpları ve bunun anlatıya yansıyıș biçimini ele alan çalışma, 1990 sonrası anlatılarda erkekliğin öznellik, hiyerarşi, dil, mekân ve cinsiyetler ile ilişkisine odaklanmaktadır. Türsel ya da yapısal sınırları aşan ve bir üst dil oluşturan bu gelişme ticari ya da sanatsal amaçlı metinlerde tekrar eden bazı söylem stratejilerinin ortaya çıkışını barındırmaktadır.

$\mathrm{Bu}$ bağlamda çalışma, metinleri dönüştüren temel dinamik olarak sosyolo-ekonomik dönüşüme vurgu yaparken, bu dönüşümün cinsiyet söylemleri ve erkeklik hegemonyası üzerinde yarattığı etkiye odaklanmaktadır. Bu bağlamda sosyoloji kavramı etkileşim, hegemonya, toplumsal cinsiyet ve erkeklik kavramları ile birlikte ele alınmaktadır. Çalışma anlatıların içsel yapısına odaklanmamakta, metinlerde tekrar ederek sürekli üretilen belirli kalıp ve stratejilere odaklanmaktadır. İncelemede adı geçen filmler 1990 sonrası Türk sinemasında erkeklik kavramını merkezi bir sorun haline getiren ve bu konuda tematik bütünlükler oluşturan filmlerdir.

\section{Film İncelemeleri: Anlatılarda Tekrar Eden Farklı Stratejiler}

a. Anti-kahraman ve Negatif Özne: Hiyerarşik ve himayeci bir söylem tarafından üretilen aktif özneye karşı, Yeni Türk Sineması, belirgin olmayan bir özne ya da anti kahraman söylemi ortaya çıkarmıştır. Anti kahraman, geleneksel kahramanın aksine cesaret, metanet ve yüksek hayat idealleri gibi kavramlardan yoksundur. Anti kahramanların kendi dünyaları üzerinde kontrolleri yoktur ve çaresizliklerinden pek rahatsız değillerdir (Elmacl, 2012).

Yüceltilecek ve özdeşleşilecek bir karakter değillerdir. Olumsuz ve özdeşleşmenin mümkün olmadığı erkek özneler 1980'li yıllarda kadın filmleri ile belirginlik kazanmıştır. Türk Sineması'nda özdeșleşmenin mümkün olmadı̆̆ı öncü anti-kahramanlardan biri Atıf Yllmaz'ın Mine (1983) filminde koca rolünü oynayan Cemil'dir. Bir kasabada yaşayan Mine tüm bakışların (ve kamera bakışının) merkezindedir. Öykü açıkça Mine ile kasabaya gelen bir yabancıyı bir araya getirmeye çalışırken; Mine'nin kocası Cemil olumsuz, istenmeyen ve öykünün dişına itilmek istenen bir özne olarak belirir. Öykü'de bakışın merkezi konumunu kadın alırken, erkekler bakışın iki yanına doğru itilmiştir. Olumsuz ve başarısız erkek özne temsillerinin bir başka örneği Atıf Yılmaz filmi Bir Yudum Sevgi'deki (1984) Cuma karakteridir. 4 çocuk babası Cuma, kahve hayatı yüzünden ailesine sahip çıkmaz. Kumar parası için kolayca mahalleliyi dolandırmaya kalkar, yalanı ortaya çıktığında utanmaz. İşyerinde hak ettiği parayı alamadığında patrondan hakkını istemek yerine işyerinden malzeme çalar. Cuma'nın erkekliğine dair en önemli gönderme ise Cuma'nın cinsel anlamda başarısız ancak bu başarısızlıktan rahatsızlık duymayan biri olarak temsil edilişidir. Cuma öylesine başarılı bir anti-kahramandır ki karısı onu terk edip mahalleden başka bir erkekle birlikte olduğunda seyirci Cuma ile değil, karısı ve aşığı Cemal ile özdeşleşir. Geleneksel Türk Sinema anlatıları için bu oldukça sıra dışı bir tutum ve yönelimdir. Her iki filmde de anlatı ve bakış kadın merkezlidir. Öykülerdeki tüm karakterlerin ve anlatının bakış yönünü kadın olușturur. Olumsuz erkekler bu merkez konumu işgal eden kadınların istedikleri ve izin verdikleri kadar bakıșa girebilmekte aksi takdirde öykünün dışına itilerek yok edilmektedirler. Mine filminin sonunda, Mine ve yazar sevgilisi bir evden birlikte çıkarken Mine'nin kocası Cemil sadece önüne bakar ve oradan gider, çerçevenin dışına çıkar, eylemde bulunamaz. Bu anlatılardaki temel sorun 
kadınların iki erkek arasında temsil edilmesi ve kadının anti-kahramana karşı, kahraman rolünü oynayan erkek karaktere yönelmesidir. Yeni Türk Sineması ise farklı bir strateji izleyerek, kadını iki erkek temsili arasında göstermek yerine, anti-kahramana karşı tekil bir özne olarak gösterir. Anti-kahramanın rakibi kahraman erkek değil, onu ve himayesini istemeyen kadın öznedir. Artık sorun himaye edemeyen erkek üzerinden münferit bir vaka olarak değil, himayenin kendisi üzerinden ele alınır. Himayecilik ve erkeklik yeni Türk Sineması'nın temel çatışmalarından biri olarak belirir.

Başka ve kahraman bir erkek olmadan, erkek himayesinin reddedilmesi bağlamında 1990 yılında vizyona giren Boynu Bükük Küheylan önemli bir aşama kat eder. Küheylan'ın karıları, 1980’lerdeki örneklerde olduğu gibi başka bir erkek ya da aldatma gibi öykülerle Küheylan'ı terk etmezler. Küheylan'ın karıları sadece Küheylan'ı ve onun himayesini istemezler. Öykü sonunda baba Küheylan öykünün ve perdenin dışına itilirken oğul Küheylan çerçeveye girer ve değișeceğine dair monolog ile filmi sonlandırır. 1990 yılında başlayan bu gelenek Yeni Türk Sineması'nda sürekli tekrar eder, Masumiyet (1997), Tabutta Rövaşata(1996), Hokkabaz (2006), Başka Dilde Aşk (2009), Çoğunluk (2010) gibi birçok örnek hayatına çeki düzen veremeyen, özne olarak beliremeyen himaye kuramayan ya da himayesi istenmeyen erkekleri öykünün merkezi haline getirir.

b. Karakterin Ölümü ya da Açık Uçluluk: Geleneksel filmler hegemonik ideolojinin ve aktif öznenin ürettiği bir son ile öyküyü sonlandırırken, Yeni Türk Sineması bu tür kapanımlara izin vermemektedir. Erkekliğin sorun haline getirildiği birçok film erkekliğin tekrar üretilmek istendiği ama başarılamadığı durumda karakterlerin öldürüldüğü veya öykünün belirsizlik ile kapatıldığı bir suskunluk durumuna yönelmektedir. Eşkıya (1996) ya da Yazı-Tura (2004) filmleri öyküyü kapatmak için karakteri öldüren önemli örneklerdir. Eşkıya filmi erkekler arası mücadelenin sessiz nesnesi olan Keje ile bu mücadeleye kendi öznelliğini yansıtan Emel'in karşıtlığı üerine kurulur. Emel'in olaylara müdahalesi öykünün geleneksel kapanımına izin vermez ve erkek karakterleri ölüme sürükler. Geleneksel kapanıma ulaşmadığı için erkek karakterin öldürüldüğü bir diğer örnek de Yazı-Tura filmidir (Oktan, 2008). Babam ve Oğlum (2005) ve Eşkıya filmleri erkeklerin bir şekilde kadınları kaybetmesi, gerçek ya da simgesel Baba ile barışma ve ölüm temaları ile sonlanır. Anlatıyı ölüm ile kapatmayan filmler ise açık bir anlatı ile sonlanmaktadır. Boynu Bükük Küheylan (1990), Tabutta Rövaşata (1996), Masumiyet (1997), Uzak (2002), Hokkabaz (2006) ve Ahlat Ağacı (2018) gibi örnekler ortaya koydukları sorunu ölüm ile çözmemekte, işlevsiz bir geleneksel kapanıma yönelmemekte ve öyküyü kapatamadıkları için anlatıyı açık bir son ile bitirmektedirler.

c. Zamanı yadsımak: Şimdiki zamanda açık uçluluk, ölüm ve bunalımın yok edilemeyişi ile buna karşı zaman ve mekânda hareket ederek bütünlük arayışı Yeni Türk sinemasının ürettiği bir diğer stratejidir. Farklılaşan bu stratejiler Cem Yılmaz'ın oyuncu olarak yer aldığı filmografisi içinde bir arada görülebilmektedir. Cem Yılmaz filmlerini iki ayrı eksene yerleştirmek mümkündür. Bir tarafta öykünün zaman ve mekânda yapay bir kapalılığa ulaştığı metaforik filmler, diğer tarafta öykünün şimdiki zamanda geçtiği ancak kapanamadığı gerçekliğin bir parçasını temsil etmeye çalışan metonimik öyküler mevcuttur. Öykünün şimdiki zamanda geçtiği ve alegorik bir ilke tarafından kapatılmadığı metonimik öykülerde sorunun kaynağı her zaman kadın olarak belirir. Bu öykülerde çoğu kez haklı olarak gösterilen kadın erkek karakterden himaye yeteneğini göstermesini ister ya da himayeyi bütün olumlu çağrışımlarına rağmen kendi öznelliği lehine reddeder. Her Şey Çok Güzel Olacak (1998), Hokkabaz (2006), Pek Yakında (2014) gibi filmler 
erkeklerin himaye yeteneğinin ve himayenin kendisinin arzulanabilirliğinin tartışmaya açıldığı filmlerdir. Aile, tek başına sürdürülmesi gereken bir kurum olmaktan çıkar.

Cem Yllmaz filmografisinde öykülerin şimdi ve burada geçtiği metanomik filmler yapay bir biçimde kapatılsa da mutlu sona ve koşulsuz takdire izin vermez. Arzu ve mutluluk ancak zaman ve mekânın terk edildiği farklı bir zaman ve mekânda üretilmiş metaforik öykülerde mümkün olur. Uzayda geçen bir Keloğlan masalı anlatan GORA (2004), masalın yapısal unsurlarını tekrar üretirken iyi prenses ile fakir ama zeki Arif'in aşkına izin verir. Uzaylı bir prenses ile dünyalı Arif'in arasındaki ilişki toplumsal cinsiyet çatışmalarına dokunmadan mutlu aşka evirilebilmektedir. GORA filminde üretilen kodlar ve kapanan anlatı AROG (2008) filminde de mevcuttur. Cem Yllmaz filmografisi böylece, Yeni Türk Sinemasının zaman ve mekâna yönelik ürettiği iki farklı söylem stratejisini de kullanmaktadır. Bir tarafta şimdiki zamanda himayeci erkekliğin imkansızlığı, kadın kimliği ve aile kavramları üzerinde yaşanan hareketlilik ve erkekliğin bunalımı, diğer tarafta şimdiki zamanda yaşanan bu ego yaralanmasına karşı zaman ve mekânın ötesinde yaratılan kapalı öyküler ve egonun onarılması söz konusudur. Cem Yılmaz özelinde açıklanan zaman ve anlatı stratejisindeki farklılaşmayı, son dönem Türk Sineması'nın birçok örneğinde görmek mümkündür. $\mathrm{Bu}$ anlatılarda şimdiki zamanın belirsizlik ve bunalımına karşı "nostalji" yoluyla kimlik üzerinde bir restorasyon üretme yoluna gidilmektedir.

d. Mekânı Yadsımak: Şimdiki zamana karşı geçmişe ve nostaljiye yönelen Yeni Türk Sineması; kent ve toplumsal cinsiyet pratiklerinde yaşanan dönüşümlere karşı kent dışına ve taşraya yönelmiştir. Taşra, kentin tehditlerine karşı aile ve erkekliğin istikrar sağlayabildiği bir yer olarak belirmiştir. Buna karşı arzuyu kışkırtmaz, tekdüze ve sıkıcıdır. Mekân ve erkeklik arasındaki ilişki ve farklılaşma en belirgin biçimde Nuri Bilge Ceylan filmografisinde görülmektedir. Nuri Bilge Ceylan sinemasının etrafında döndüğü tematik söylemi ilk filmi KOZA (1995) ile ortaya koymuştur. Mekân, zaman ve cinsiyet KOZA'dan beri Nuri Bilgi Ceylan sinemasının merkezinde duran izleklerdir. Koza filminde taşrada yaşayan bir adam ile kentten gelen ve aralarında sorun olduğu belli olan kadının ilişkisi imgesel bir dil ile anlatılır. Zamanın geçişi, ailenin fotoğrafları, ölen hayvan görüntüleri, rüzgârda savrulan otlar ve ağaçlar zamana yenik düşmüş bir ilişkiyi anlatacak şekilde kurgulanmıștır. Bu öykü içinde bir simgesel olay, tematik anlatımı destekler nitelikte yer bulur. Anlatıdan bağımsız olarak köyde dolaşan bir çocuk ve filmin sonuna doğru bu çocuğun yıktığı, parçaladığı arı kovanları görülür. Nuri Bilge Ceylan'ın taşrada kurduğu bu imgesel öyküyü İstanbul ve vapur görüntüleri böler, İstanbul ve kent karşı bir güç olarak metne yerleşir. Kent ile taşra, Nuri Bilge Ceylan'ın ilk dönem filmlerinde beden açısından net olarak ayrıșır. Kasaba (1997) ve Mayıs Sıkıntısı (1999) mekâna, mekânda sıkışmış insanlara ve bu insanların ruh halleri etrafından şekillenen imgesel bir anlatıya dayalıdır. Bu filmler kırsal alanda geçer, kadın, beden ve arzuya dair belirgin söylemler yoktur. Bu öykülerde görülen kadınlar anne, abla gibi geleneksel çerçevedeki yerlerini korurlar. Uzak filmi ile kente yaklaşmaya başlayan Nuri Bilge Ceylan sineması bedene de yaklaşmaya başlar ve erkeklik sorunu belirginleşir. Kentteki kadınlar geleneksel rollerinin dışına çıkmaya başlarlar. Kocasını aldatan bir kadın, kürtaj nedeni ile çocuk sahibi olamayan Mahmut'un eski karısı, Yusuf karakterinin peșine düştügü kadınlar, televizyonda seyredilen bedenler, Mahmut'un izlediği porno film, Mahmut'un bir arkadaş ortamında sorduğu "kadın yok mu?" gibi bir soru, öyküyü mümkün olduğunca kadın ve arzuya yaklaştırır. Uzak filminde fotoğrafla ilgili ideallerini kaybetmiş Mahmut'u iki sahnede fotoğrafla ilgilenirken görürüz. Evine çağırdığı kadınla birlikte olduğu sahne 
ve Mahmut'un Yusuf'a sebepsiz yere bağırdığı sahneleri, fotoğraf çekme sahneleri takip eder. Vicdan ve suçluluk duyguları Mahmut'u fotoğraf çekmeye iter. Her iki durumda da fotoğraf çekmek bir araçtır (Akbulut, 2005, s.150). Kadın ve taşralı ise Mahmut'un içe kapalı dünyasını anlamak için var olan araçlar olarak belirir, öykünün merkezinde kentli erkek vardır. Bu noktada Nuri Bilge Ceylan filmografisi itirafçı bir seviyeye yükselir, taşra ve taşralıya yönelen kamera aslında ifade edilemeyen suçluluk duygusundan, himayenin reddi ve vicdan azabından kaçmak içindir buna karşı bedene yönelik salt bir hazcılık Mahmut'u belirler. Nuri Bilge Ceylan kente ve şimdiki zamanda geçen olaya dayalı anlatılara yaklaştıkça öyküde kadın ve kadın ile kurulamayan ilişki belirginlik kazanır. İklimler filminde, kentte bir öykü anlatmaya kalkışan yönetmen imgesel öykülerin arasına sevişme ve beden sahneleri koyar. İstanbul'da ve şimdiki zamanda sorunları aşamayan öykü iklimlerle işaret edilen zamana ve Kars'a dek uzanan mekanlara yayılır. 3 Maymun kent yüzeyinde geçen bir başka beden, arzu ve iktidar öyküsüdür. Nuri Bilge Ceylan kente yaklaştıkça bedenler açlır, görünür ve evrensel temaların yerini bedene dair vurgular almaya başlar. 3 Maymun filminde ter, beden, ifrazat görüntüde belirgin bir ağırlık kazanmaya başlar (Özenç, 2011).

Taşrada geçen Ahlat Ağacı, Nuri Bilge Ceylan filmografisi içinde en çok diyalog bulunduran filmdir. Küçük bir kasabada bir tür toplumsal panorama yaratan yönetmen; baba, arkadaş, iş adamı, din adamı, sanatçı, aile, aşk gibi kavramlara yönelir. Bu filmin temsilinde stratejik olan yön erkeklerin mümkün olduğunca çok konuşmasına karşı kadınların sessizliği ve konuşmayışıdır. Erkeklerin içine düştüğü çıkmazda kadınlar bunalımı derinleştiren, çerçeveyi süsleyen birer fazlalık gibi dururlar. Öykü, huzursuz ve mutsuz bir aile etrafında gelişir. Sorumsuz ve kumarbaz "Baba" filmin sonuna kadar ailenin yaşadığı sorunların müsebbibi olarak varlığını korur. Bu sırada öykü kitabını basmaya çalışan Sinan, kasabada yaşayan değișik toplumsal tiplerle derinlemesine diyaloglar geliştirir. Ancak anne ve kız kardeş film içinde karikatür bir tipleme olmanın ötesine geçmeyi başaramaz, her ikisi de Ceylan'ın kentli kadına yönelik beden ve cinsellik vurgularından yoksundur. Olan biten her şeye karşın annenin televizyon karşısında çekirdek yemesi, kız kardeşin basit diyalogları her ikisini de karakter olmaktan yoksun kılar. Öykü içinde karşılaşılan bütün karakterler duygu ve düşünceleri ile açılırken, bu iki kadın karakter bir fazlalık olarak yer alırlar, öykü içinde var ama anlatı dinamikleri içinde yok gibidirler. Buna karşı öykü içinde karşılaşılan bir diğer kadın karakter Sinan’ın bir arkadaşının sevgilisidir. Uzaklara gitmek isteyen, kendi arzuları olan bu karakter, taşranın tekdüze ve himayeci tavrına meydan okur. Ağaçlıkta geçen diyalog esnasında Sinan'dan sigara ister, Sinan'a sebep yokken bir öpücük kondurur. Kenti ve özgürlüğü işaret eden tek kadın, beden, arzu, oyun ve rekabet kavramlarını beraberinde getirir. Ceylan sinemasının mekân ve kadın ayrışmasını tekrar üretir. Tüm bu kadın karakterler, erkekler arasındaki ilişkileri anlamamızı sağlayan yardımcı figürler olarak vardırlar. Bir tarafta derinlikten yoksun ve kaderini erkeğe teslim etmiş kadın karakterler diğer tarafta erkekliği ve himayeciliği tehdit eden kadın karakter söz konusudur, erkekler ise bu iki dinamik arasında sadece birbirleri ile konuşmaktadırlar.

Ceylan özelinde açıklanan erkeklik ve mekân arasındaki ayrışma Yeni Türk Sineması'nın birçok örneğinde tekrar üretilen bir temsil biçimidir. Taşra bu bağlamda mekân sosyolojisine dayalı bir gerçeklik olarak değil, kente karşı üretilen bir imge olarak yükselir. Erkeklik ve aileye yönelik bunalımdan kaçınmak isteyen birçok popüler film ve televizyon dizisi İstanbul dışına çıkarak, nostaljik öyküler üretmiş ve geleneksel "aşk, aile, mutluluk" söylemini üreterek ticari bir başarı elde etmiştir. 
e. Kadınsızlaşan Anlatılar: Yeni Türk Sineması 1980 ve doksanların başında çerçevenin ve anlatının dișına itilen erkekleri merkeze alırken, buna ek bir strateji olarak kadını çerçevenin dışına itmiştir. Hegemonyanın istikrarsızlaşmasına karşı müzakere ve yeni bir uzlaşı üretemeyen erkeklik kendisine odaklanmıştır. Bu bağlamda erkek filmlerinin en belirgin özelliği kadının yokluğudur. Bu filmlerde kadın erkekler tarafından görüldüğü ve anlaşıldığı şekli ile vardır (Suner, 2005, s.291). Yeni Türk Sineması erkeklik bunalımlarına odaklansa da erkek merkezli tavrını devam ettirmektedir.

Küreselleşme, kapitalistleşme ve kentleşme kadının toplumsal konumunu hızla dönüştürürken, erkekler bu yeni dünyada nasıl konuşacaklarını, nasıl bir dil edineceklerini bilmemektedirler. Bu durumda anlayamadığı her şeye küfür eden Gemide (1998), Laleli'de bir Azize (1999) gibi örnekler; şiddet, hakaret ya da depresyonu erkekliğe içselleştiren ticari filmler Recep İvedik serisi ya da olayların akışına boyun eğmekten başka çaresi olmayan Zeki Demirkubuz'un erkek karakterleri perdeyi kaplar. Üslup ve anlatı ne kadar değişirse değişsin anlatı erkek merkezli olmaya başlamış ve kadın erkekliğin bu durumunun altını çizen bir unsura dönüşmüștür.

Zeki Demirkubuz, erkeklik ve himayecilik krizini en "sade" dil ile anlatan ve doğrudan bu konuya yönelen bir yönetmen olarak belirir. Kadın, erkek üzerinde bir şiddet unsuru olarak belirir ancak Demirkubuz bu esnada hegemonyasını kaybeden erkekliğin, erkek öznenin kendisine ve kadına yönelik yarattığı şiddeti ve geleneği sorgulamaya devam eder. Zeki Demirkubuz sineması içinde anlatıda en az kadın olan ve tamamen erkekler arası ilişkiye odaklanan film Yeraltı (2012) filmidir. Dostoyevski'nin Yeraltından Notlar isimli eserinden esinlenerek yazılan senaryo Zeki Demirkubuz Sineması'nın kadınlarla ilişkisini, erkeklik üzerinden ortaya koyan önemli bir temsil niteliğindedir. Öykü erkekler arası bir hiyerarşi savaşını konu edinir. Öyküye "kadın" sadece erkek karakterlerin egolarının toplumsal konumunu işaret etmek üzere dahil olmaktadır. Fahişeler, ev temizlikçileri ve görünen tüm kadınlar erkeklerin hegemonik ilişkilerinin ve yaralanmış egolarının altını çizmek üzere vardır.

f. Kadın Düşmanlığı: Kadının perde ve anlatı dışına itilmesi ve erkek kimliğine yönelik mazlumlaştırıcı söylemler, üstü kapalı bir kadın düşmanlığından beslenir ve üretir. Tür veya kategori ayrımı yapmaksızın kadın düşmanlığının izlerini Yeni Türk Sineması'nın birçok örneğinde bulmak mümkündür. Bir korku filmi örneği olarak Semum (2008) eğitimli ve bekar kadın düşmanlığını herhangi bir sembolik stratejiye başvurmadan doğrudan doğruya söyleme dökmekte ve evlenmemiş eğitimli kadını cehennemde gösteren bir sahne ile anlatıyı bitirmektedir. Sadece diyaloglara yaslanan popüler bir sistem eleştirisi parodisi olan Mandıra Filozofu (2014) kadın düşmanlığının açıkça sergilendiği bir diğer örnektir. Kapitalist kent yaşamını popüler bazı motifler etrafında ele alan film, kapitalizmin doğayı talan etme arzusunun arkasında anlayışsız, cahil ve gösterişçi kadınların olduğunu iddia ederek tüm eleştirel tutarsızlığını kadın düşmanlığına aktararak ilerici ve eleştirel olma iddiasına bürünür. Rekabet, güç, erkeklik, kapitalizm ve doğanın yok edilişi arasındaki ilişkiyi gizleyerek ve kadınlığa aktararak film ideolojik bir çarpıtmayı da ortaya koyar. Kadın düşmanlığının en popüler örneği ise "Recep İvedik" serisi içinde yer almaktadır. Kadınlar tüm seri boyunca bedenleri, varlıkları, yaşları gibi nedenlerle aşağılanır. Anlatının merkezinde sadece moderniteye eklemlenme konusunda başarısız olmuş bir erkekliğin, travmatik narsizmini temsil eden erkek karakter bulunmaktadır. 
g. Sadece Arzu Nesnesi Olarak Temsil Edilen Kadın: 1990’lı yıllar gelenek ve siyasal olan tarafından tayin edilemeyen kamusal alanın, bireysel bir hazcılık ile dolduruluşuna sahne olmuştur. Herhangi bir toplumsal dayanaktan yoksun bireyler için, eğlence ve haz yükselen bir değer olarak var olmuştur (Bauman, 2017). Toplumsal bağları zayıflamış ve tüketim ekonomisinin kültürel yapısı ile şekillenen orta sınıflar için beden ve cinsellik önemli bir tüketim kalıbı olurken, geleneksel himaye ve aile kalıplarına sahip çıkmanın reddi yeni bir erkek kimliğine işaret etmektedir. Kaybedenler Kulübü (2010) ya da Issız Adam (2008) gibi örnekler bu sosyolojik eğilim üzerine yükselir. Sebepsiz ayrılıklar ve sunulan aşkı sebepsiz reddedişler, estetize edilmiş bir gündelik yaşam ve bunalım söyleminden elde edilen artı-değerin tüketimi geleneksel himayeciliğin reddi ve tüketici bir erkek kimliğini işaret eder. Sorumluluk almaktan uzaklık, estetize edilmiş gündelik yaşam, bireysel ve sınıfsal sorunların inkârı bu öykülerin anlatılarını olușturur. Her iki öykü de orta sınıflar üzerine kurulmuş marjinal, romantik ve suya sabuna dokunmayan öyküler olarak belirmektedir (Özizmirli, 2011).

h. Erkek Dayanışması ve Baba'nın Aranışı: 70’li yıllarda Amerikan toplumu feminist hareket ile karşılaşmış ve sinemada o güne dek varlığını koruyan temsil biçimleri varlığını koruyamamıştır. Sinemada ve toplumda erkek egemen anlatıların sorgulanmaya başlanması Amerikan sinemasında erkek dayanışmasına dayalı dostluk filmlerinin yükselişine sahne olmuştur. Bu dönemin Amerikan filmlerinde öz korumacı bir bağlanma ve kadınlara yönelik öfke belirgindir (Ryan ve Kellner, 1997, s.236-237). Ryan ve Kellner'in Amerikan sinemasına yönelik bu tespiti 1990 sonrası beliren Yeni Türk Sineması içinde kullanılabilir. Erkekliğin, kadının onaylayıcı bakışından yoksun kaldığı anlatılarda erkekler kendilerine yönelik bir bakış geliştirmekte ve erkek dayanıșmasına yönelik öyküler üretmektedirler. Yeni Türk Sineması'nın başarısız erkekleri yoğun olarak Baba'yı ve babanın düzene soktuğu hiyerarşik toplumu arar. Hegemonyayı tekrar üretecek bir Baba/düzenleyici ilkenin varlığı ya da yokluğu temel sorunlardan biridir. Tabutta Rövaşata, Hokkabaz, Babam ve Oğlum, Eşkıya, Kabadayı ve Ahlat Ağacı gibi anlatısı değiş̧ik üsluplara ve konulara sahip birçok film Baba'nın varlığı ya da yokluğunun yarattığı eksiklik ile simgesel/gerçek baba ile barışma motifleri üzerine kuruludur. Tüm öykülerde himaye kurmayı başaramayan ya da himayesi reddedilen erkek karakter, baba figürünün kurucu ve kollayıcı gücüne ihtiyaç duyar.

Handan İpekçi ve Yeşim Ustaoğlu filmlerinde de babanın aranışı ya da yokluğu önemli bir sorundur. Her iki kadın yönetmen de baba figürünü devlet ve otorite sembolizmi ile yoğun bir ilişki içinde ele alırken, kadın karakterleri kimliğin taşıyıcısı, toplumsal belleğin mekânı olarak ele alırlar. Handan İpekçi'nin Büyük Adam Küçük Aşk (2001) filminin erkekleri etnik ve ulusal kimliklere işaret edecek şekilde konumlanırken, kadın karakterler Hejar ve Sakine Kürt kimliğinin taşınması, ilan edilmesi ve yadsınmasını işaret eder. Bu bağlamda erkeklik -ve kadınlık- erkek merkezli cinsiyetçi bir karşıtlık içinde değil, milliyetçi söylemin cinsiyeti milletle eşleștiren sembolizmine benzer bir söylem içinde ele alınır. Yeşim Ustaoğlu filmlerinde de otoriteyi temsil eden baba filmlerde yok gibidir (Arslan, 2010, s. 109). Kimlik, hafıza ve hatırlamayı "kadın" karakterler üzerinden ele alan Ustaoğlu, bir otorite figürü olarak reddeder. Her iki kadın yönetmende başarısız ve çaresiz erkekleri \babaları perdeye taşır. Ancak söylemlerini devlet ve kimlik üzerinden işaret eden anlatılarında kadınlığın ve erkekliğin tekil temsili arka planda kalır. Cinsiyetler diğer evrensellik, ulusallık ve etniklik gibi diğer çatışma alanları ile ilişki içindedir.

i. Susan/Konuşamayan Erkekler: Sinemada kadın sessizliği ve konuşamayan kadınlar birçok çalışmaya konu olmuştur. Yeni Türk Sineması'nda ortaya çıkan olgu ise 
konuşamayan erkeklerdir. Sessizlik ve konuşamamak farklı kavramlardır. Barutçu (2015), çalışmasında erkeklerin ev içi sessizliklerini otoritelerine yönelik somut veya soyut bir saldırıyı savuşturmak için kullanılan stratejik bir davranış olarak ele almaktadır. Ancak konuşmamaktan farklı olarak konuşamamak, kendini ifade edememek, himayeci bir dilden yoksun olmayı, sözü işaret ettiği şeyle eşleştirecek otoriteden yoksun olmayı ya da bilinçte bir bulanıklığı ifade eder. Erkeklik krizi suskunluğa karşı, çok ve durmadan konuşan ama anlamlı bir örüntü oluşturmayan erkek temsillerini de doğurmuştur. Bu çok ve anlamsız konuşma halini Gemide ya da Kaybedenler Kulübü gibi filmlerde ya da eğlenceye dayalı komedilerde görmek mümkündür.

Konuşamayan erkeklerin ilk etkili örneklerinden biri Bir Yudum Sevgi filmindeki Cuma karakteri kabul edilebilir. Karısı ve dört çocuğu kendisini terk ederken, bütün mahalle karısı ve Cemal arasında yaşananlar hakkında dedikodu yaparken, Cuma ağzını açıp kendisini veya olayları yorumlayacak anlamlı cümleler kurmaz. Cuma karakterinin kendi doğasından kaynaklanıyormuş gibi görünen bu sessizlik ve suskunluk zamanla Yeni Türk Sineması'nın önemli motiflerinden biri haline gelmiştir. Boynu Bükük Küheylan filminde güçlü, çıkarcı ve gelenekçi Küheylan şehir hayatında bütün himaye gücünü ve otoritesini kaybeder ve köyüne dönerek suskunluğa gömülür, konuşma yeteneğini kaybeder. Filmin sonunda oğul Küheylan, kameraya dönük olarak doğrudan seyirciye yönelen bir monolog gerçekleştirir ve babasının dilini kullanmayacağını; himayeci olmayan, uyum sağlayan bir kişilik üreteceğini ilan eder.

Derviş Zaim'in 1996 yılında çektiği Tabutta Rövaşata filminin Mahsun'u konuşmaz, ağzında sürekli tekrar eden bazı kelimeler vardır. Mahsun'un konuşma ve cümle kurma denemeleri kahvehanede tanıştığı uyuşturucu bağımlısı kadınla kurduğu kısa süreli ilişkide gerçekleşir. Himaye ve ailenin imkansızlığı anlaşıldıktan sonra Mahsun sessizliğine ve kelimelerle kurduğu muğlak ilişkiye geri döner.

Erkek sessizliği Nuri Bilge Ceylan sinemasının ana temalarından biri olarak belirir. Uzak filminde Yusuf'un konuşkanlığına, kadınlara yönelik arzularını ifade edişine ve canlılığına karşı; Mahmut'un sessizliği, konuşamayıșı ve sinikliği tam bir karşıtlık oluşturur. Nuri Bilge Ceylan filmlerinde erkek sessizlikleri 3 Maymun, İklimler ve Ahlat Ağacı gibi filmlerde etkili ve önemli bir leitmotif olarak varlığını sürdürür.

Erkek sessizliğinin, otoriter bir kültürle ilişkilendirildiği ve erkeğin kendini ifade edemeyip kelimelerle sürekli oynadığı bir diğer örnek 2010 yapımı Seren Yüce filmi Çoğunluk'tur. Politik göndermeler de barındıran filmde, Mertkan karakteri çoğunluk ve otorite karşısında kendini ifade etme becerisinden yoksun ve bunu gizlemek için sağa sola ve özellikle kadınlara küfür eden bir karakter olarak belirir. Mertkan Kürt bir kızla ilişki yaşamaktadır ancak baskıcı babasının altında geliştiremediği erkekliği ilişkisini himaye etmesine izin vermez. Baba'nın kuralcı konuşkanlığına karşı, oğulların iradesizlikleri ve suskunlukları Çoğunluk filminin ana karşıtlığını kurar.

Yeni Türk Sineması'nda erkeğin bir dil olușturamayıșı ve konuşamayışının doğrudan anlatının konusu olduğu film ise Başka Dilde Aşk'tır. Öykü, duyamayan ve duyamadığı için konuşamayan Onur ile iş koşulları altında sömürülen ve çıkış yolu bulamayan Zeynep arasındaki duygusal ilişkiyi ele alır. Baba figüründen yoksun iki karakter kendilerini duygusal bir ilişkinin içinde bulurlar. Her iki karakterin de diğerine ihtiyacı vardır ancak iletişim ve erkeğin konuşamayışı, konuşamadığı için yaşadığı korku ilişkiyi bir çıkmaza sürükler. Yeni Türk Sineması'nın erkekleri ile kadınları arasındaki ilişkinin doğasını öykü içinde Zeynep'in sorduğu sembolik bir soru belirler, "Hiç konuşmadan anlaşabilir miyiz?" 
Film cinsiyetler arası bölünme ile diğer mücadele alanlarının işlerliği arasındaki ilişkiyi bir arada ele almakta ve erkek sessizliğini önemli bir sembol olarak kullanmaktadır.

j. Yönlü veya Yönsüz Şiddet: Yeni Türk Sineması'nda şiddet yükselen bir olgu olarak belirir. $\mathrm{Bu}$ anlatılarda şiddet, kendini ifade edemeyen, konuşamayan ya da hegemonik erkekliğin taleplerine uyamayan erkeklerin ürettiği bir olgudur. İktidarsız erkeklerin ürettiği şiddetin öncü örneklerinden biri Eşkıya filminde, sevgilisi Emel'in kendisini aldattığını ögrenen Cumali'nin Emel ve sevgilisini öldürmesidir. Gemide filmi bir çaresizlik ve şiddeti bir arada ele alan bir erkek öyküsü olarak belirir. Ezilmiş ve dünyayı anlayamayan erkekler kapalı dünyalarında bir kadına eziyet ederler. Uyguladıkları bütün şiddete rağmen zayıf ve beceriksizdirler, hem mağdur hem de zalimdirler. Kadın karakter tüm sessizliği ve pasifliği ile erkeklerin şiddetini boşa çıkarır. Erkeklerin bütün zayıflı̆̆ı ve çaresizliği, eli kolu bağlı bir kadın tarafından ortaya çıkarılır (Pekerman, 2012, s.51-56). Masumiyet filminde Zeki Demirkubuz erkekliğe yönelen şiddeti bütün öyküye yayar, erkekler aşk ve arzunun peşinde kimliklerine yönelik yıkıcı bir şiddete maruz kalmaktadırlar. Buna karşı Zeki Demirkubuz geçmişi yüceltmez, geçmişten kaynaklanan şiddet ve kadın suskunluklarının temsili -geleneksel şiddet yüzünden dili parçalanan Yusuf'un kardeşi ve erkek şiddeti yüzünden konuşamayan Çilem- erkekliğin geçmiş yorumunu da sorunlu hale getirir. Gönül Yarası (2005) filmi geleneksel erkekliğin himayesini reddeden bir kadının, kurtarıcı bir baba arayışı ve cumhuriyet ideallerine yönelik umutsuzluğu bir arada ele alır. Filmin kadın karakteri himayeci erkek tarafından öldürülür. Barda (2007) üretilemeyen erkekliğin ürettiği şiddetin en sert anlatımlarından biridir. Erkekliğini kent yüzeyinde ifade edemeyen erkeklerin girdikleri erkeklik rekabeti içinde girdikleri utanç döngüsü, her yöne saçılan ve sonu gelmez bir şiddete dönüşür.

$\mathrm{Bu}$ bağlamda Yeni Türk Sineması'nın cinsiyet ve erkeklik ile ilişkili ürettiği tematik bütünlükler, incelenen filmlerle birlikte Tablo 1'de bir araya getirilmiştir.

Tablo 1: Anlatılarda Cinsiyete Dayalı Ortaya Çıkan Tematik Bütünlükler

\begin{tabular}{|c|c|}
\hline Anti Kahraman Negatif Özne & $\begin{array}{l}\text { Mine (1983), Bir Yudum Sevgi (1984), Boynu Bükük Küheylan } \\
\text { (1990), Tabutta Rövaşata (1996), Eşkıya(1996), Masumiyet (1997), } \\
\text { Hokkabaz (2006), Başka Dilde Aşk (2009), Çoğunluk (2010) }\end{array}$ \\
\hline $\begin{array}{l}\text { Karakterin Ölümü ya } \\
\text { da Açık Uçluluk }\end{array}$ & $\begin{array}{l}\text { Boynu Bükük Küheylan (1990), Eşkıya (1996), Her Şey Çok Güzel } \\
\text { Olacak (1998), Uzak (2002), Yazı Tura (2004), Babam ve Oğlum } \\
\text { (2005), Masumiyet (1997), Hokkabaz (2006), Ahlat Ağacı (2018) }\end{array}$ \\
\hline Zamanı Yadsımak, Nostalji & Gora (2004), Arog (2008), Vizontele (2001), Babam ve Oğlum (2005) \\
\hline Mekânı Yadsımak & Koza (1995), Kasaba (1997), Mayıs Sıkıntısı (1999), Ahlat ağacı (2018) \\
\hline Kadınsızlaşan Anlatılar & $\begin{array}{l}\text { Gemide (1998), Lalelide Bir Azize (1999), Recep } \\
\text { İvedik Serisi, Uzak (2002), Yeraltı (2012) }\end{array}$ \\
\hline Kadın Düşmanlığı & Semum (2008), Mandıra Filozofu (2014), Recep İvedik Serisi \\
\hline Salt Arzu Nesnesi Olarak Kadın & Issız Adam (2008), Kaybedenler Kulübü (2010) \\
\hline $\begin{array}{l}\text { Erkek Dayanışması ve } \\
\text { Babanın Aranışı }\end{array}$ & $\begin{array}{l}\text { Tabutta Rövaşata (1996), Eşkıya(1996), Masumiyet (1997), } \\
\text { Büyük Adam Küçük Aşk (1999), Hokkabaz (2006), Babam } \\
\text { ve Oğlum (2005), Kabadayı (2007), Ahlat Ağacı (2018) }\end{array}$ \\
\hline Susan\Konuşamayan Erkekler & $\begin{array}{l}\text { Bir Yudum Sevgi (1984), Boynu Bükük Küheylan (1990), Tabutta Rövaşata } \\
\text { (1996), Uzak (2002), Başka Dilde Aşk (2009), Çoğunluk (2010) }\end{array}$ \\
\hline Yönlü ve Yönsüz Şiddet & $\begin{array}{l}\text { Eşkıya (1996), Gemide (1998), Lalelide Bir Azize (1999), } \\
\text { Masumiyet (1997), Gönül Yarası (2005), Barda (2007) }\end{array}$ \\
\hline
\end{tabular}

\section{Sonuç}

Türkiye kültür dünyasının erkeklik kavramını modernleşmenin başladığı Tanzimat'tan beri kadın, gelenek ve aile kavramları ile bir arada ele aldığı görülmektedir. Tanzimat 
ile beliren bu temalar geleneksel sinema anlatılarının da konusunu oluşturmuş ancak anlatılar nihai aşamada geleneksel ideolojinin yönlendirmesi ile kapanmış ve içe kapalı bir öykünün yarattığı ego bütünlüğü oluşturulmuştur.

1950 sonrası yaşanan toplumsal dönüşüm, cinsiyet davranışlarının ve erkekliğe dair hegemonik söylemin işlevsizleşmesini doğurmuştur. 1950 ve sonrasında yaşanan kentleşme süreci geleneksel toplumun yaklaşı 40 yll içinde göç yolu ile kentleşmesini ve parasallaşan, sözleşmeli bir yaşam biçimi içine dahil oluşunu üretmiştir. Bu süreç toplumsal cinsiyet kalıplarında statüye bağlı üstünlüklerin aşılmasını ve sorgulanmasını beraberinde getirmiștir. 1980’li yıllara kadar metni geleneksel ideolojinin hegemonik taleplerine göre şekillendiren anlatılar 1980'lerde kadın kimliğinde yaşanan pratik dönüşümlere odaklanmıştır. 1980'li yıllarda yaşanan bu gelişmeyi 1990 ve sonrasında ortaya çıkan erkek bunalımına yönelik filmler takip etmiştir. Erkeklik krizine yönelik anlatılar incelendiğinde sürecin nitelikli bir söylem ve hegemonya bunalımını içerirken, erkekliğe yönelik çok boyutlu temsil stratejilerini ürettiği görülmektedir.

Burada ilk göze çarpan unsur erkekliğin negatif bir özne çerçevesinde temsil edilmesi ve himaye kavramının sorunsallaştırılmasıdır. Erkekliğin bunalımına yönelik bu tür anlatılar karakterin ölümü ya da öykünün açı uçlu bırakılması ile tamamlanmaktadır. Erkekliğin şimdiki zaman ve mekânda yaşadığı bunalıma karşı üretilen ve kapalı anlatıyı mümkün kılan strateji ise zaman ve mekanda hareket ederek öykü üretmektir. Ancak birçok öykü zaman ve mekandaki bu kaçışın da yapay bir kaçış olduğunu işaret etmektedir. Yine de birçok ticari film bu stratejinin olanaklarından yararlanarak tarihsel ya da komedi filmleri üreterek başarılı olmuştur. Şimdiki zamanda ve burada geçen anlatılarda yükselen önemli bir strateji erkekliğin restorasyonuna yönelik öyküler üretmektir. Bu anlatılarda öyküdeki kadının yok edilmesi ve perdenin dışına itilmesi, kadın kimliğine yönelik bir düşmanlığın üretilmesi ya da kadının salt bir arzu nesnesi olarak temsil edilmesi anlatıyı şekillendirmektedir.

Yeni Türk Sineması, Tanzimat'ta beliren ve uzun süre varlığını koruyan kodları bu kez yazarı ve himayeci kültürcü alegoriyi arka planda bırakarak ya da işlevsizleştirerek ele almaktadır. Ancak bu filmler müzakere üretmek yerine erkek kimliğine odaklanarak, erkek merkezli söylemi yeniden üretmektedir. Metinler erkeklik ve himayecilik üzerinden şekillenen bunalıma odaklansa da erkek merkezli yapısını korumaktadır. Bu nedenle öykü ve anlatı, açllmak, eleştirel bir dil geliştirmek yerine içe kapanmaya, melankoliye odaklanmaya ve suskunluğu ön plana çıkarmaya başlamıştır. Buna karşı Handan İpekçi ve Yeşim Ustaoğlu gibi kadın yönetmenlerin cinsiyetleri, etnik ve ulusal aidiyetlerle ilişki içinde ele alarak cinsiyet bunalımı yerine, aidiyet sorununa odaklandığı görülmektedir. Seren Yüce ise Çoğunluk filminde hiyerarşik himayecilik, erkeklik ve aidiyet sorunlarını bir arada ele alarak çok yönlü bir anlatının olanaklarını oluşturmaktadır, hiyerarşik himayeciliğin ürettiği ötekileştirme ve iradesiz erkek çocuklara odaklanmaktadır. Nihai aşamada Yeni Türk Sineması'nın bir çok toplumsal mücadele alanına yayılan anlatılar üretmiş olmasına karşın, cinsiyet ve erkeklik sorunun diğer konuları şekillendiren "üstbelirleyici" bir konum edindiği görülmektedir.

\section{Notlar}

1 Kadın ve erkek arasında doğal farklılıklara, dolayısıyla hukuksal sorumluluk ve haklarda farklıı̆̆a işaret etme şeklinde okunabilir. Himayecilik, kadının erkeğe(baba-koca) tabii olmasını, erkeğin reisliğini, kadının hukukta, ekonomide veya eğitim alanlarında kısıtlı oluşu gibi ön kabulleri içerir.

2 Lale Devri ile başlayıp II. Abdulhamid yönetimine kadar olan süreçte, kadınların kıyafetlerine, kamusal alanda yer alış şekilleri ve zamanlarına kadar artan oranda padişah iradesi ilan edildiği görülmektedir. Yine Tanzimat’tan sonra yaşanan 
bürokratikleşme süreci devletin aile ve kadın konusunda idari-yasal kararlar ürettiğini göstermektedir. Bu yasallaşma süreci geleneğin gözetiminde gerçekleşse de sürecin, kadının teorik-yasal eşitliğine yönelik gelişimi ürettiğini göstermektedir (AvCl, 2009).

3 Ahmed Cevdet Paşa, Ma'ruzat (1980; s.9) adlı eserinde "Zen-dostlar çoğalıp mahbublar azaldı. Kavm-i Lut sanki yere battı. İstanbul'da öteden berü delikanlılar için ma'ruf u mu'tad olan aşk u alaka, hal-i tab'isi üzre kızlara müntakil oldu" yazmaktadır. Cevdet Paşa bu ifadesini kadınların kamusal alana artan oranda çıkışını ifade etmek için kullanırken, bu durumu tüketim, israf, gösteriş ve zina gibi konularla ilişkilendirir (Delice, 2012). Ek olarak aynı pasaj "erkeklik" denilen kavramın muğlakkığına ve inşa edilebilirliğine işaret eder.

4 Ayrıca bu dönemde kadınlar çıkardıkları dergi, gazete ve buralarda beliren tarısşmaları ele aldıkları konak ya da hayır derneklerindeki toplantılara katılarak yeni bir kamusal alanı genişletmekteydi (Berktay, 2010, s. 95). Gazete ve dergi gibi yayın organlarının kentleşmiş ve zorunlu tarım emeğinden farklı bir nüfus yapısına işaret ettiğinin altı çizilmelidir.

5 Bu dönem edebiyatında "artık mutlakçı ve ataerkil bir sultanın otoritesine eskisi gibi yaslanmayan mutlakçı bir kültür, simgesel babasını arıyordu (Parla, 2009, s.15)."

6 Cumhuriyetin anayasal devlete dayalı eşitlik ilkesi, eşitsizliğin yasallaşıııılığı bir bağlam üretmiştir. Devlet kamusal alanı düzenlerken, özel alan kültürcü bir bakıış açısı tarafından düzenlenmiş ya da düzenlenmemiştir. 1924 Anayasası 10. Maddesi "her Türk" kavramı yerine kadınların da eşit haklara sahip olduğunun vurgulanması talebine karşın, "her erkek Türk" şeklinde düzenlenmiştir. Böylece yurttaşlık hakları ve kamusal alan "erkek"leri işaret eden bir eşitlik ve özgürlük tanımı ile şekillenmişstir. Buna karşı özel alanı yönlendiren kültürel kabuller, Türkiye'de ve Avrupa'da 1990'lı yıllara kadar süren aşamalı dönüşümlerle eşitlik lehinde düzenlenmiş̧tir (Berktay, 2010, s. 35-64).

7 Bu yapıyı tekrar üreten ancak görsel dilini farklı bir şekilde üreten Lütfü Akad'ın Vesikalı Yârim (1968) filmi üretim yılı ile de bu konuda önemli bir dönüşümü işaret eder.

\section{Kaynakça}

Akbulut, H. (2005). Nuri Bilge Ceylan Sinemasını Okumak. İstanbul: Bağlam Yayıncılık.

Arslan, M. M. (2010). Yeşim Ustaoğlu Su, Ölüm ve Yolculuk. İstanbul: Agora Kitaplığı.

Atay, T. (2004). "Erkeklik” en çok erkeği ezer. Toplum ve Bilim(101), 11-30.

Avcl, Y. (2009). Osmanlı Devleti'nde Tanzimat Döneminde "Otoriter Modernleşme" ve Kadının Özgürleşmesi Meselesi. Osmanlı Tarihi Araştırma ve Uygulama Merkezi Dergisi, 21(21), 1-18.

Barutçu, A. (2015). Bir erkeklik stratejisi: özel alanda eril suskunluk. Fe Dergi, 7(1), 131145.

Bauman, Z. (2000). Siyaset Arayışı. (T. Birkan, Çev.) İstanbul: Metis Yayınları.

Bauman, Z. (2017). Akışkan Modernite. (S. O. Çavuş, Çev.) İstanbul: Can Sanat Yayınları.

Berger, J. (2014). Görme Biçimleri. (Y. Salman, Çev.) İstanbul: Metis Yayınları.

Berktay, F. (2010). Tarihin Cinsiyeti. İstanbul: Metis Yayınları.

Bourdieu, P. (2015). Ayrım. (D. F. Şannan ve A. G. Berkkurt, Çev.) Ankara: Heretik Yayınları.

Castel, R. (2017). Ücretli Çalışmanın Tarihçesi. (I. Ergüden, Çev.) İstanbul: İletişim Yayıncılık.

Colin, G. D. (2006). Kadın, İslam ve Sinema. İstanbul: Agora Kitaplığı.

Connell, R. W. (1998). Toplumsal Cinsiyet ve İktidar. (C. Soydemir, Çev.) İstanbul: Ayrıntı Yayınları.

Delice, S. (2012). 'Zen-dostlar Çoğalıp Mahbûblar Azaldı': Osmanlı'da Toplumsal Cinsiyet, Cinsellik ve Tarihyazımı. C. Çakırlar ve S. Delice içinde, Cinsellik Muamması: Türkiye'de Queer Kültür ve Muhalefet (s. 329-363). İstanbul: Metis Yayınları.

Demiray, E. (1999). Türk Sineması'nda 1960-1990 Yılları Arasında Çekilmiş Filmlerde Kentsel Aile . Eskişehir: T.C. Anadolu Üniversitesi Yayınları. 
Demren, Ç. (2019, 9 11). Erkeklik, ataerkillik ve iktidar ilişkileri. Hacettepe Üniversitesi Kadın Sorunları Araştırma ve Uygulama Merkezi: http://www.huksam.hacettepe. edu.tr/Turkce/SayfaDosya/erkeklik_ataerklik.pdf adresinden alındı

Elmacı, T. (2012). Gemide ve Bornova Bornova Filmleri Bağlamında Yeni Türk Sineması'nda Antikahramanın Yükselişi. Selçuk Üniversitesi İletişim FAkültesi Akademik Dergisi , $7(2), 168-181$.

Fiske, J. (2013). İletişim Çalışmalarına Giriş. (S. İrvan, Çev.) Ankara: Pharmakon Yayınevi.

Han, B.-C. (2015). Şiddetin Topolojisi. İstanbul: Metis Yayıncılık.

Işın, E. (2006). Tanzimat Ailesi ve Modern Adab-ı Muaşeret. H. İnalcık ve M. Seyitdanlıoğlu içinde, Tanzimat (s. 405-418). Ankara: Phoenix Yayınevi.

Kabadayı, L. (2013). Film Eleștirisi: Kuramsal Çerçeve ve Sinemamızdan Örnek Çözümlemeler. İstanbul: Ayrıntı Yayınları.

Kahraman, H. B. (2010). Cinsellik Görsellekik Pornografi. İstanbul: Agora Kitaplı̆̆ı.

Keyder, Ç. (2004). Ulusal Kalınmacılığın Íflası. İstanbul: Metis Yayınları.

Lefebvre, H. (2007). Modern Dünyada Gündelik Yaşam. İstanbul : Metis Yayınları.

Maral, E. (2004). İktidar, erkeklik ve teknoloji. Toplum ve Bİlim(101), 127-143.

Mead, G. H. (2017). Zihin, Benlik ve Toplum. Ankara: Heretik Yayınları.

Moran, B. (2017). Edebiyat Kuramları ve Eleștiri. İstanbul: İletişim Yayınları.

Mulvey, L. (1989). Görsel Haz ve Anlatı Sineması. Visual and other pleasures, 14-26.

Oktan, A. (2008). Türk Sinemasında Hegemonik Erkeklikten Erkeklik Krizine: Yazı-Tura ve Erkeklik Bunalımının Sınırları. Selçuk Üniversitesi iletişim Fakültesi Akademik Dergisi, 5(2), 152-166.

Onur, H. ve Koyuncu, B. (2004). “Hegemonik” erkekliğin görünmeyen yüzü: Sosyalizasyon sürecinde erkeklik oluşumları ve krizleri üzerine düşünceler. Toplum ve Bilim(101), 31-49.

Ortaylı, İ. (2014). Osmanlı Toplumunda Aile. İstanbul: Timaş Yayınları.

Özden, Z. (2004). Film Eleştirisi. Ankara: İmge Kitabevi.

Özenç, T. B. (2011). Nuri Bilge Ceylan Sinemasında Bedene Üç Maymun`un Perspektifinden Bakış: "Sadelikten Başka Sığınak Yok...". Birikim Dergisi(268-269), 24-28.

Özizmirli, G. (2011). Orta Sinıf «Hikayeleri». Birikim(268-269), 18-23.

Parla, J. (2009). Babalar ve Oğullar. İstanbul: İletişim Yayınları.

Paşa, A. C. (1980). Ma'ruzat. İstanbul: Çağrı Yayınları.

Pekerman, S. (2012). Film Dilinde Mahrem. İstanbul: Metis Yayınları.

Ritzer, G. ve Stepnisky, J. (2014). Ssoyoloji Kuramları. (H. Hülür, Çev.) Ankara: De Ki Basım Yayım.

Roper, J. (2005). Symmetrical Communication: Excellent Public Relations or a Strategy for Hegemony? Journal Of Public Relations Research, 17(1), 69-86.

Ryan, M. ve Kellner, D. (1997). Politik Kamera . İstanbul: Ayrıntı Yayınları.

Simmel, G. (2005). Modern Kültürde Çatışma. İstanbul: İletişim Yayınları. 
Suner, A. (2005). Hayalet Ev. İstanbul: Metis Yayınları.

Tekeli, İ. (2006). 19. Yüzyılda İstanbul Metropol Alanının Dönüşümü. H. İnalcık ve M. Seyitdanlığlu içinde, Tanzimat (s. 381-392). Ankara: Phoenix Yayınevi.

Ulusay, N. (2004). Günümüz Türk Sinemasında "erkek filmleri”. Toplum ve Bilim(101), 144-161. 


\title{
Crisis of Hegemonic Manhood and Masculinity Forms in New Turkish Cinema
}

\author{
Doğan Aydoğan (Asst. Prof. Dr.)
}

\section{Extended Abstract}

It is seen that the New Turkish Cinema has developed a new style and has narratives that use the film language effectively. However, no matter how different their subjects and styles differ it is seen that New Turkish Cinema produces narratives that focus on the masculinity crisis as a general tendency. In addition, the central position of masculinity as a problem in narratives began with the Tanzimat Era. Concepts arising from the European Enlightenment, such as legal equality, private property and constitutional citizenship have begun to influence social life with the Tanzimat Edict. But there is a conflict between the idea of constitutional equality and traditional patronage. While public legal order is based on the idea of equality among citizens legal arrangements for the private sphere are determined by culture. The conflict between these two spheres has maintained its potential throughout the modernization process. However, the rapid urbanization after the second world war and the emergence of a new social structure produced a structure in which the status advantages inherited from tradition became dysfunctional and the produced social practice by women displaced the patronage of masculinity. This development emerged qualified identity crisis in terms of male identity that identifies itself with patriarchal discourse and patronage masculinity. For this reason, Turkish Cinema which focused on presentation of female identity with the effect of military coup in 1980 s focused to narratives with a negative male presentation in 1990s.

Film and advertising narratives have been male-centered throughout modern history. The classical cinema texts which were shaped according to the man's voyeurism fantasy; created a narrative shaped by actions of male character at the center to the male-centered audience. In these narratives, women have either adapted to the order demanded by men or have been pushed out of the social order or women who are the object of uncontrollable desire were fetishized and removed from social reality. On the other hand, advertising texts addressed the male consumer for a long time and in these texts masculinity was opened to competition and associated with consumption.

In the current situation, while the traditional narratives created by the cinema text in favor of patronage and culture remain dysfunctional, advertising texts have begun to produce discourses in which a male identitiy produces himself as a sexual object. With these developments, male identity which lost its traditional patronage position is focused on itself, its social position, body and depression in cinema, daily life and commercial films. Similarly New Turkish Cinema produced a structure carrying the male identity crisis to the narrative center.

Meanwhile, there are some basic themes produced by New Turkish Cinema. At the forefront of these themes is the fact that a negative and unwilling male subject replaces the patronage male profile that shapes events and takes active action for social and individual demands. This male subject is not represented by active patronage but by a dysfunctional crisis. Another phenomenon that emerged in the New Turkish Cinema is the open-ended stories and the death of male characters. The author who unable to provide narrative integrity and satisfaction with traditional methods, chooses to leave the story 
open-ended and unsolved or to kill male characters. Another theme that arises about the problem of masculinity is the replacing the time and space. Stories that cannot produce a solution to the current crisis in the present tended to the past or the future and produced nostalgic stories in which the problem of patronage and masculinity is unobtrusive. In the meantime, films directed in the countryside and the provinces brought the emphasis on place. This films emphasis to rural place and life against to developments in the city and the public sphere. Another thematic trend is the decrease in female characters in narratives and the increase in solidarity or events among men. In these narratives, women exist as a marker or social sign of the relationship between men. In addition it is seen that some narratives -fear or comedy- clearly includes misogyny and have achieved significant commercial success. Another important thematic unity that emerged in this period is the representation of men leaning on middle-class, and rejecting a patronizing, culturalist identity. These men in narratives do not take any social and cultural responsibility, their only purpose in life is the female body as the object of desire. Another important phenomenon that emerged in this period was that the character who represented by the negative subject and the unsuccessful masculinity is looking for a patronizing and guarding father figure. The demand for social norms to be put in hierarchical place by an authoritarian father is a common feature seen in many films in the New Turkish Cinema. In the absence of the father's symbolic and practical power the density of non-speaking and silent men is another thematic unity produced by New Turkish Cinema. Accompanied by all these elements, it is seen that the violence arising from masculinity in the New Turkish Cinema is intense. But this violence is multi directional and variable. It can be directed to the male characters self as a symbolic violence, directed to the woman by the man or becomes a random violence.

Accompanied by all these explanations, it is seen that New Turkish Cinema developed a new style and created a narrative tradition based on masculinity. Although many areas of social struggle take place in narratives it is seen that the categories of masculinity and gender are positioned as an upper principle determining the stories.

Keywords: Hegemonic Masculinity, New Turkish Cinema, Gender, Sociology. 
